\title{
$41919=$
}

\section{Povos expostos, povos figurantes ${ }^{1}$ Georges Didi-Huberman}

Tradução de Maria da Luz Correia

\section{Saídas da fábrica, entradas em cena}

O primeiro filme projetado da história tem por título, como é sabido, $A$ saída da fábrica Lumière. No dia 22 de março de 1895, na rua de Rennes em Paris, diante de cerca de duas centenas de espetadores, Auguste e Louis Lumière expuseram pela primeira vez, numa tela, o povo humilde em movimento (figura 1). Os seus próprios operários tinham sido enquadrados diante do portão da fábrica de Monplaisir, abandonando as suas oficinas, num intervalo do trabalho, pelo meio-dia. É, então, saindo da sua fábrica que os povos terão entrado em cena - terão beneficiado de um novo valor de exposição na era do cinematógrafo. Tudo isto é bastante simples, está visto, mas também muito paradoxal.

Esta origem, com efeito, não teria existido se não tivesse surgido de surpresa. Os irmãos Lumière, provavelmente, não teriam qualquer intenção de dar destaque ao seu povo humilde de empregados. Eles estavam sobretudo orgulhosos de apresentar em Paris um processo original de fotografia a cores, chamado "autocromo". Mas foi sem dúvida o "cinetoscópio de projeção" mostrado mesmo no final da sessão, que fez, para sua própria surpresa, a surpresa maravilhada do público: "Através de um cinetoscópio de sua invenção, M. Louis Lumière projetou uma das mais curiosas cenas: a saída do

\footnotetext{
${ }^{1}$ A presente tradução tem base na versão deste texto reproduzida entre as páginas 141 e 159 da seguinte obra de Georges Didi-Huberman: Didi-Huberman, G. (2012) Peuples Exposés Peuples Figurants, L'oeil de I'histoire, 4, Paris: Les Éditions de Minuit. Note-se que, embora este excerto corresponda às primeiras três secções da quarta parte do livro Peuples Exposés Peuples Figurants, L'oeil de l'histoire 4, cujo título é Poémes de peuples, adotámos aqui o título Povos Expostos, Povos Figurantes, seguindo a opção tomada numa anterior versão deste mesmo excerto: Didi-Huberman, G. (2009), Peuples exposés, peuples figurants, De(s)générations, 9, 2009, 7-17. Optamos por respeitar as normas de citação originais.
} 
pessoal das oficinas à hora de almoço. Esta vista animada, mostrando em pleno movimento toda a gente apressando-se para a rua, produziu o mais surpreendente efeito..." ${ }^{2}$. Em alguns segundos, víamos surgir uma centena de pessoas, como se esse "povo da imagem" (os operários de Lyon) invadisse de repente a alta sociedade dos engenheiros e dos promotores industriais (os espetadores de Paris) vindos à sessão.

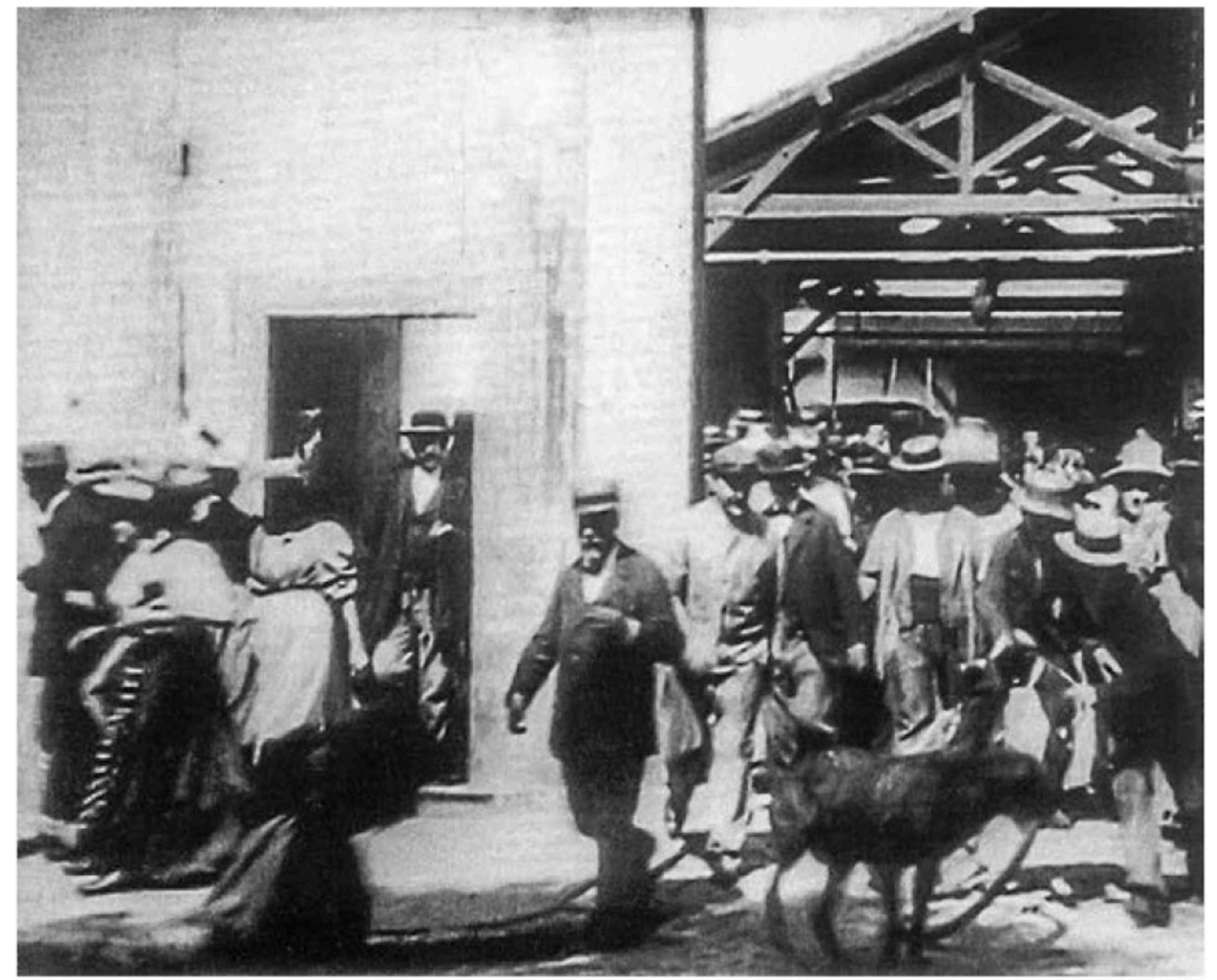

Figura 1: Auguste e Louis Lumière, $A$ saída da fábrica Lumière, 1895, Fotograma do filme.

Por outro lado, esta origem não teria existido se não tivesse surgido na diferença criada entre os sujeitos representados e o modo da sua exposição: são, com efeito, trabalhadores mostrados no próprio ato de abandonar o seu trabalho. Não há violência reivindicativa nesta saída, claro: os operários aproveitam simplesmente a pausa do meio-dia para apanhar ar, enquanto o seu patrão, ele, aproveita a luminosidade do sol, necessária à realização técnica do seu filme. Mas a diferença está precisamente aí e a vários níveis: trabalhadores - fabricantes de material fotográfico -, os operários tornamse de repente os atores deste primeiro filme. Um deles, que passa de bicicleta, chama-

\footnotetext{
${ }^{2}$ Bulletin du Photo-Club de Paris, 1895, $\mathrm{n}^{\circ} 3$, citado por B. Chardère, Le Roman des Lumière. Le cinéma sur le vif, Paris, Gallimard, 1995, p. 301.
} 
se Francis Doublier: algum tempo mais tarde, passará atrás da câmara com um novo estatuto social, o de operador cinematográfico ${ }^{3}$.

Um terceiro paradoxo aparece logo que descobrimos que esta origem não existiria se não se tivesse desenrolado inteiramente no elemento da repetição. A película de celuloide de março de 1895 foi, com efeito, precedida pelo seu "ensaio geral" ${ }^{4} \mathrm{em}$ suporte papel - por isso, não projetável - no verão de 1894; ela foi sucedida por outras "repetições" ou versões da mesma cena até ao final do século ${ }^{5}$. Acrescentemos que, medindo a fita apenas dezassete metros - para um total de cerca de oitocentos fotogramas ou "vistas", como se dizia então -, o filme não durava mais de um minuto, "de maneira que uma repetição desta projeção foi pedida por toda a plateia maravilhada"

Esta origem, enfim, nada tem, curiosamente, de um ponto de partida: ela aparece mais como um território ainda impreciso, um campo de possibilidades abertas e relativas, não ao valor intrínseco do novo médium técnico, mas aos múltiplos valores de uso que ele, pouco a pouco, assumirá. Basta folhear o catálogo das "vistas Lumière" para compreender o significado considerável de que se reveste o cinematógrafo para uma história da exposição dos povos: é, com efeito, o corpo social por inteiro, sob todas as suas latitudes, que se torna no final do séc. XIX o objeto principal deste novo atlas do mundo em movimento: corridas de touros e concursos de bebés; manifestações políticas e procissões religiosas; azáfama citadina, mercados de fruta e de legumes; trabalho dos estivadores, dos pescadores, dos camponeses; recreações e jogos de crianças; lançamentos de navios; equipas de desporto e trupes de circo, lavadeiras e bailarinos Ashantis, opulentos burgueses em Londres e coolies miseráveis em Saigão, etc. ${ }^{7}$.

Toda a questão reside em saber, afinal, de que maneira e em vista de quê estas "vistas" se expunham. Sabemos que a figuração dos povos representa um desafio crucial para todo o cinema primitivo e moderno para além - ou a partir - de $A$ Saída da fábrica

\footnotetext{
${ }^{3}$ Ibid., p. 293.

${ }^{4}$ No texto original, "répétition générale". Há, ao longo deste parágrafo, um jogo de palavras com o duplo sentido da palavra francesa répétition, que significa em simultâneo repetição e ensaio, [Nota da Tradutora].

${ }^{5}$ Ibid., p. 293-301. G. Sadoul, Histoire générale du cinéma, I. L'invention du cinéma, 1832-1897, Paris, Denoël, 1948 (ed. revista e aumentada, 1973), pp. 284-286. N. Burch, La Lucarne de l'infini. Naissance du langage cinématographique, Paris, Nathan, 1990, pp. 22-28.

${ }^{6}$ Bulletin du Photo-Club de Paris, op. cit., p.301.

${ }^{7}$ Cf. J. Rittaud-Hutinet, Auguste et Louis Lumière: les mille premiers films, Paris, Philippe Sers Éditeur, 1990. P. Dujardin, "Domitor ou l'invention du quidam”, L'aventure du cinématographe. Actes du congrès mondial Lumière, Lyon, Aléas, 1990, p. 277: "O tempo do cinematógrafo é o tempo onde o povo vem a ser figurado, seja este apreendido sob a categoria do amontoado urbano e laborioso, seja este apreendido sob a categoria política do quidam, isto é, o qualquer um elevado à dignidade de sujeito de direito".
} 
Lumière $^{8}$. Isto vai de Griffith a Eisenstein, de Abel Gance a King Vidor. Sem esquecer Fritz Lang, que se preocupa com as multidões manipuladas em Metropolis antes ainda de Leni Riefenstahl as glorificar, uns anos mais tarde e já com um verdadeiro ditador, em $O$ Triunfo da Vontade ${ }^{9}$. Compreende-se bem, nestas condições, a urgência política - e a dificuldade conceptual - de uma análise dos fenómenos "mediáticos" na era dos totalitarismos vitoriosos, manifesta em pensadores como Kracauer, Brecht, Benjamin ou Adorno $^{10}$. Não basta, então, que os povos sejam expostos em geral: é preciso ainda perguntar-se, em cada caso, se a forma de uma tal exposição - enquadramento, montagem, ritmo, narração, etc. - os fecha (isto é, os aliena e, no fim de contas, os expõe ao desaparecimento) ou os abre (os libera ao expô-los à comparência, concedendo-Ihes, assim, uma força própria de aparição).

\section{O povo imaginário}

"O cinema”, escreveu Edgar Morin, "dá-nos a ver o processo de penetração do homem no mundo e o inseparável processo de penetração do mundo no homem", num ponto preciso, num plano de charneira dialética que atua como operador de conversão. Ora, esse plano não é outro senão a imagem propriamente dita, a imagem que "não é apenas a placa giratória entre o real e o imaginário, [mas ainda] o ato constitutivo radical e simultâneo do real e do imaginário ${ }^{11 "}$. Se o homem do cinema é, então, esse homem imaginário que Edgar Morin sugere, não é, de todo, para que nele se vá diagnosticar apenas o homem da fuga e da ilusão, o homem do irreal e da ignorância, o homem do apolitismo e da indiferença ao mundo. Quando os operários Lumière saíram da sua oficina e se moveram em plena luz do dia, maiores que o seu tamanho real no ecrã de projeção, diante do grupo siderado dos espetadores burgueses da rua de Rennes, era talvez já de um encontro político que se tratava, encontro suscitado pela imagem e não desfasado do real, pois relacionando - e para a longa duração do desenvolvimento social do cinema - os operários e os empresários ou clientes de uma mesma indústria emergente.

Jean Louis Scheffer, naquele que é talvez o seu mais belo livro, esboçou uma poética, quase uma metapsicologia deste "homem imaginário" dando-lhe o nome de homem comum, "homem sem qualidades" do cinema. É quando a nossa solidão diante da

\footnotetext{
${ }^{8}$ Cf. J.-L. Leutrat, “Modernité. Modernité?”, Lumière, le cinema, Lyon, Institut Lumière, 1992, pp.64-79.

${ }^{9}$ Cf. P. Sorlin, "Foule actrice ou foule-objet? Les leçons du premier cinéma", L'Image. Études, documents, débats, $\mathrm{n}^{\circ} 1,1995$, pp. 63-74.

${ }^{10}$ Cf. M. Girard, "Kracauer, Adorno, Benjamin: le cinéma, écueil ou étincelle révolutionnaire de la masse?", Lignes, N. S., $\mathrm{n}^{\circ} 11,2003$, pp. 208-225.

${ }^{11}$ E. Morin, Le Cinéma ou l'homme imaginaire. Essai d'anthropologie sociologique, Paris, Minuit, 1956 (ed. 1977), p. IX e p.208.
} 
imagem se torna - por meio do medo, segundo Scheffer - consistência de um corpo social, à qual a nossa solidão seria permeável ou da qual estaria imbuída. "O que é projetado e animado não somos nós e, todavia, nós reconhecemo-nos aí (como se um estranho desejo de extensão do corpo humano [...] pudesse atuar aqui). [...] Não é possível que a minha experiência do cinema seja completamente solitária: isso, mais do que a ilusão que ele nos dá do movimento e da mobilidade das coisas, é a ilusão própria do cinema; [...] parece, e devido a esta solidão artificiosa, que uma parte de nós mesmos é permeável a efeitos de sentidos sem nunca poder chegar à significação pela nossa linguagem [...] O cinema age sobre todo o ser social como sobre um ser solitário. ${ }^{12 "}$ É provável que o homem do cinema seja um sujeito "comum" - e não um connaisseur, como na arqueologia ou nas artes plásticas - na medida em que ele contempla o movimento dos aspetos humanos a partir da sua própria situação de quidam imerso, juntamente com os seus semelhantes da espécie humana, na penumbra geral de uma sala de projeção. Na medida, também, em que este "estranho desejo de extensão do corpo humano" se move na sala escura como grãos de poeira no feixe do projetor, entre corpos imóveis da sombra (os espetadores) e corpos em movimento da luz (os atores). Qual é então o ser coletivo resultante deste encontro, o ser social do cinema? Impossível, sem dúvida, deduzir a ideia só a partir do casting (os atores chamados ao ecrã) ou só a partir da audiência (esse público cuja comunidade e cuja solidão não sabemos geralmente pensar). É antes o encontro - e não apenas a "representação" de um lado, não apenas a "receção" do outro - que tornaria possível uma eventual construção desta ideia.

Ora, este encontro depende, de cada vez, de um certo estado histórico das relações entre poética e política. Jacques Rancière faz corresponder a Gustave Flaubert a ideia tipicamente moderna segundo a qual, "em matéria de arte [...] não há mais nem bons nem maus assuntos: Yvetot vale Constantinopla e uma filha de camponês uma aristocrata $^{13}$." Mas poderíamos também perfeitamente fazer corresponder esta economia da figuração aos Palafreneiros de Caravaggio, aos Vagabundos de Callat, aos Mendigos de Rembrandt, ou mais tarde, aos Desastres de Goya. Sobre a base desta longa história na qual se desenrola o "teatro do povo", Jaques Rancière questionou com igual pertinência "as ideias dominantes de um tempo e de uma intelligentsia que pensam [hoje] que, no que diz respeito ao povo, nós já demos definitivamente o suficiente e até já demos demasiado", isto a propósito do valor

\footnotetext{
12 J. L. Schefer, L'Homme ordinaire du cinéma, Paris, Cahiers du cinéma-Gallimard, 1980, pp. 11-12 e p. 102.

${ }^{13} \mathrm{~J}$. Rancière, "Le bruit du peuple, l'image de l'art (à propos de Rosetta et de L'Humanité)" (1999), Théories du cinéma, dir. A. de Baecque e G. Lucantonio, Paris, Cahiers du cinéma, 2001, p. 214.
} 
sintomático de filmes recentes como A Humanidade de Bruno Dumont ou Rosetta dos irmãos Dardenne ${ }^{14}$.

O diagnóstico de Jaques Rancière pode ser precisado em dois sentidos simétricos. Por um lado, parece que os povos se expõem ao risco de serem hipostasiados - e sobretudo, reduzidos - numa entidade maior e mais consensual, ao mesmo tempo, que é a ideia de nação ${ }^{15}$. É o que dá lugar às identificações massivas, às coreografias militares e às narrativas de mérito patriótico, de Busby Berkeley aos heróis simpáticos e triunfantes de O dia da independência. É isto que reúne ilusoriamente a "trupe" que se exibe e o "público" que a julga ${ }^{16}$. É isto que permite, com a ajuda da tecnologia digital, criar exércitos, sociedades inteiras, sobre a base de um simples algoritmo de clonagem, tipo Matrix ou O Senhor dos Anéis. Face a isso, os arcaicos bandos de mortos-vivos, na série de filmes realizados por George A. Romero, aparecem como uma alternativa política ao populismo dos vivos-demasiado-vivos que se movem, de maneira completamente intermutável e alienada, nos ecrãs das nossas sitcoms ${ }^{17}$.

Por outro lado, os povos expõem-se ao risco de ser hipostasiados na entidade limitada disso que designamos por pic people, isto é, o "povo das imagens" - picture e não mais image - segundo a definição que deste dá a muito chique revista Vogue, especializada nas entertainment industry news, nas celebrity photos e nas box offices, como o indica a sua publicidade: ora, ela designa por pic people "todos aqueles que participam na existência de um filme", desde os mais modestos técnicos até aos grandes atores e desde os produtores até aos proprietários das salas de cinema ${ }^{18}$. Philippe-Alain Michaud cita esta definição no contexto de um percurso onde a noção de povo acaba por, infelizmente, dar lugar ao people das stars e dos happy fews que hoje enlouquece o mundo do espetáculo e da arte contemporânea: assim, o "mendigo" de Accatone tornase ídolo e o mártir - ou o estilita antigo, tudo isto sob a designação, sempre americana, da fashion victim - é visto como uma categoria da moda, enfim, uma criação de estilista. $^{19}$

O pic people define-se, indiscutivelmente, por uma concorrência tipicamente capitalista dos adereços característicos, conforme Joseph Mankiewicz o encenou bem em filmes

\footnotetext{
${ }^{14}$ Ibid. p. 213-219. Cf. id., "Le théâtre du peuple: une histoire interminable" (1985), Les Scènes du peuple (Les Révoltes logiques, 1975-1985), Lyon, Horlieu Éditions, 2003, pp. 167-201.

${ }^{15}$ Cf. J.-M. Frodon, La Projection nationale. Cinéma et nation, Paris, Odile Jacob, 1998. R. Rother (dir.), Mythen der Nationn: Volker im Film, Berlim-Munique, Deutsches Historisches Museum-Koehler \& Amelang Verlagsgesellschaft, 1998.

${ }^{16}$ L. Gervereau, "Échantillons ou masses symboliques? Le rôle des foules et du public à la television", L'Image. Études, documents, débats, n 1, 1995, pp. 97-123.

${ }^{17}$ Cf. J.-B. Thoret (dir.), Politique des zombies. L'Amérique selon George A. Romero, Paris, Ellipses, 2007.

${ }^{18}$ P.-A. Michaud, Le Peuple des images. Essai d'anthropologie figurative, Paris, Desclée de Brouwer, 2002, p. 23.

19 Ibid. p. $25-40$ e $195-248$.
} 
como Eva ou A condessa descalça: é sempre uma star contra outra, melhor que outra, é sempre o deslumbramento perpétuo diante de um corpo hipostasiado em imagem de marca - que não é, evidentemente, nem a imagem no sentido antropológico nem a marca no sentido do vestígio - de um desejo não muito claro. A paixão cinéfila, com a altivez que a carateriza frequentemente, gosta de se concentrar sobre "o mais bonito rosto, o melhor ator": mesmo a sua reflexão em torno de uma "política de atores" recupera, por inerência, a noção de autor e, portanto, a autoridade do nome próprio enquanto poder simbólico dessa espécie de Monte Parnaso onde se tramam os amores dos deuses Gary Cooper, John Wayne ou James Stewart ${ }^{20} \ldots$

Uma das virtudes políticas do cinema de arquivos remontados, tal como o praticam Esther Choub, Mikhail Romm, Artavazd Pelechian, Basilio Martín Patino, Jean-Luc Godard ou ainda Yervant Gianikian e Angela Ricci Lucchi, consiste em remontar a história à procura dos rostos perdidos, quer dizer, os rostos que talvez hoje tenham perdido o seu nome, que se nos oferecem no impoder e na mudez, mas que em nada perderam a sua força logo que os vemos moverem-se na luz trémula de películas danificadas pelo tempo. É esta a maneira de redescobrir uma virtude essencial do cinema "primitivo", que André S. Labarthe soube contemplar no rosto único de Falconetti filmado por Dreyer assim como no dos inúmeros sem-nome filmados por Eisenstein, esses "heróis documentais", como ele lhes chama ${ }^{21}$. É o rasto deles, em certa medida, que Harun Farocki terá procurado numa extraordinária coleção de saídas de fábricas onde o gesto inaugural dos operários de Lumière se difratava para nos acenar, com a mais contemporânea urgência política ${ }^{22}$.

\section{Os figurantes}

Desde logo, parece que o cinema não expõe os povos senão através do estatuto ambíguo dos "figurantes". Figurantes: palavra banal, palavra para os "homens sem qualidades" de uma encenação, de uma indústria, de uma gestão espetacular dos "recursos humanos"; mas também palavra abismal, palavra de labirintos que toda a figura encerra. Os figurantes correspondem, antes de mais, na economia

\footnotetext{
${ }^{20}$ Cf. L. Moullet, Politique des acteurs: Gary Cooper, John Wayne, Cary Grant, James Stewart, Paris, Éditions de l'Étoile-Cahiers du cinéma, 1993. R. Bellour, «Le plus beau visage, le plus grand acteur: Lilian Gish, Cary Grant », Trafic, n 65, 2008, p. 82-85. A contrario, uma reflexão sobre "o ecrã muito povoado [...] de figurantes e de personagens de segunda categoria, de multidões, de bandos, classes em luta e nações em guerra" aparece num texto tardio de S. Daney, "Pour une cinédémographie" (1988), Devant la recrudescense des vols de sacs à main... Cinéma, Télévision, information (1988-1991), Lyon, Aléas, 1991 (ed. revista e corrigida, 1997), pp. 124-127.

${ }^{21}$ A. S. Labarthe, "Belle à faire peur", Lignes, N. S., n 23-24, 2007, p. 394.

${ }^{22}$ H. Farocki, Arbeiter verlassen die Fabrik, 1995. Vidéo, 36 mn. Cf. Id., Reconnaître et poursuivre (19731995), textos reunidos por C. Blümlinger, trad. anónimo, Dijon-Quetigny, Théâtre Typographique, 2002, pp. 65-72 e pp.118-119.
} 
cinematográfica, a um acessório de humanidade que serve de quadro à representação central dos heróis, verdadeiros atores da narrativa, os protagonistas, como se diz. Eles são na história que se conta uma espécie de pano de fundo composto por rostos, corpos, gestos. Eles formam o paradoxo de não serem senão um simples décor, mas humano. Chamam-lhes, em inglês ou em espanhol, os extras - comparsi em italiano, Statisten em alemão -, uma maneira de indicar até que ponto não são necessários à peripécia, à dinâmica do filme. Eles são a massa obscura à frente da qual brilham as "vedetas" (aquelas que merecem ser vistas) e as stars (aquelas que comparamos a astros, esses pontos de esplendor isolados que, no céu, mantêm ainda os nomes dos deuses antigos). Os figurantes são a noite do cinema, quando se faz do cinema uma arte para fazer brilhar as suas estrelas. Eles estão para a sociedade do espetáculo um pouco como os "miseráveis" estavam para a sociedade industrial do tempo de Victor Hugo.

Os figurantes representariam então qualquer coisa como uma parte maldita da grande arte - e da grande indústria - cinematográfica. Eles situam-se na base da escala artística e social onde são ainda precedidos pelas "personagens autobiográficas", pelos "atores coadjuvantes" e outros supporting actors ${ }^{23}$. Mesmo as revistas como Cahiers $d u$ Cinéma só muito brevemente se debruçam sobre os "papéis secundários", de maneira a votar os figurantes à inexistência pura e simples, poética e politicamente falando: eles desaparecem então abaixo do último nível, ocupado pelo "terceiro homem" ou pela "personagem de segunda" 24 . Jacqueline Nacache, na sua obra de sínteses sobre $O$ ator de cinema fala a propósito do figurante como o "homem-móvel, o passante anónimo, a silhueta engolida pela sombra, o povo humilde dos filmes ${ }^{25}$.

Os figurantes não seriam atores de nada. Eles seriam os não-atores por excelência, como indica a sua definição semiológica e institucional. Definição semiológica: "Todas [as figuras humanas num filme] não são necessariamente "figuras actoriais". Em primeiro lugar, a coorte dos figurantes. A título individual, eles não têm qualquer valor actancial: são 'não-actantes', pois eles não constituem uma força ativa da narrativa. Pelo contrário, a título coletivo, eles podem fazer esse papel (as tropas que desembarcam na costa da Normandia em $O$ mais longo dos $\operatorname{dias}^{26}$ )". Definição institucional: "O figurante só está lá pela roupa que veste, a mancha de cor móvel que ele põe num décor. [...] A encenação posiciona-o, escravo consentido do cinema, subjugado às ordens

\footnotetext{
${ }^{23}$ Cf. J. Nacache, L’Acteur de cinéma, Paris, Nathan, 2003, pp. 92-99.

${ }^{24}$ Cf. T. Jousse, "Seconds rôles: l'album de famille", Cahiers du cinéma, n 407-408, 1988 (“Acteurs"), pp. 60-61. N. Rivière, "Le troisième homme et le second couteau dans le cinéma américain des années quatrevingt-dix", Brûler les planches, crever l'écran. La présence de l'acteur, dir. G.-D. Farcy et R. Prédal, SaintJean-de-Védas, L'Entretemps Éditions, 2001, pp. 339-347.

${ }^{25} \mathrm{~J}$. Nacache, L'Acteur de cinéma, op. cit., p. 98.

${ }^{26}$ A. Gardies, Le Récit filmique, Paris, Hachette, 1993, p. 60.
} 
vociferadas e à disciplina militar. Se sai da linha, põe em risco o cenário (Jerry Lewis numa das piadas de The Errand Boy [...]. Cada figurante é contratado e pago pela produção com base no seu estatuto de "não actante" ${ }^{\text {"2 }}$." Num manual profissional da corporação cinematográfica, pode ler-se que "a escolha dos figurantes cabe aos assistentes" que determinam o "número de figurantes num décor" combinando as exigências artísticas do realizador com as económicas do diretor de produção ${ }^{28}$.

Os figurantes são no plural. Se se quer falar de um figurante no singular, dir-se-á, de preferência, "um simples figurante". Simples, porque Ihe falta aquela individuação que faz a complexidade fascinante do carácter, da personagem, do ator, esse sujeito da ação. Os figurantes figuram, logo, não agem. Quando eles se movem, eles são mais movidos por um efeito de massa que os encaminha num vasto movimento, um desenho geral no qual cada figurante não é senão o segmento, o quadrado do mosaico, apenas um ponto, às vezes. A palavra figurantes, no plural, é atestada em francês por volta de 1740: ela designa um grupo de bailarinas que, à entrada de um ballet, desenham diversas figuras através do seu arranjo coletivo. Por volta de 1800, o termo é empregue para referir essas personagens de teatro que têm um papel secundário, quer dizer que estão lá, no palco, mas não têm absolutamente nada para dizer. Elas não existem, na maioria das vezes, senão pelo seu número, a sua massa, a sua muda indiferenciação. Por volta de 1907, passou a empregar-se a palavra num sentido mais geral, para evocar um grupo de pessoas cujo papel - numa sociedade ou numa situação histórica - não é precisamente nem efetivo nem significativo, como indicam bem as expressões de "papel apagado" ou de "papel puramente decorativo". Ser figurante: estar lá para não comparecer, para se fundir na massa, para não servir para nada, exceto de fundo à história, ao drama, à ação.

Apesar do seu nome, os figurantes tendem então, na maioria das vezes, a desaparecer, a não "fazer figura" já que eles "fazem de fundo", sempre atrás das figuras ativas. 0 ruído que eles emitem não é senão um rumor. A sua designação é coletiva. Se porventura os nomes dos figurantes aparecem no genérico final, as letras são tão pequenas e passam tão depressa diante dos nossos olhos que desaparecem bem depressa para dar lugar a uma simples coluna, uma lista ilegível onde é suposto que cada um figure indistintamente. Os figurantes são aqueles que não conseguiram "fazer nome" e é por isso que são tão mal pagos. Eles esperam durante horas no local de rodagem para fazer o que lhes mandam, que, geralmente, não é grande coisa. As maquilhadoras dedicam-Ihes claramente muito pouco tempo. As suas roupas são

\footnotetext{
27 J. Nacache, L'Acteur de cinéma, op. cit., p. 99.

${ }^{28}$ V. Othnin-Girard, L'Assistant réalisateur, Paris, FEMIS, 1988, pp. 77-78.
} 
frequentemente escolhidas para formar, no seu todo, uma grande mancha monocromática tão uniforme quanto possível. O protótipo do figurante é sem dúvida o mero soldado raso, que, entre as centenas ou os milhares dos seus pares, apenas está lá para figurar a batalha - da qual o herói sairá vitorioso ou então heroicamente ferido , tendo apenas de caminhar, com a baioneta levantada, e de fazer de conta que cai morto num dado momento.

Os figurantes são, assim, como os inúmeros soldados desconhecidos do cinema comercial. Eles morrem esquecidos, como cães. Não é por acaso que os figurantes designam, na gíria francesa, os cadáveres anónimos expostos na morgue à espera de ser - mas é tão raro - reconhecidos e nomeados. No Dictionnaire français-argot publicado em 1901, Aristide Bruant citava esta queixa: "O teu homem já não aparece em casa há três dias [...] Vai ver à morgue ${ }^{29}$ [...] Ele está talvez entre os figurantes" Se um amigo vos diz que fez de figurante num filme e vos convida a ir vê-lo, há uma forte possibilidade de que a sua presença no ecrã vos escape completamente. Pois tal é o paradoxo dos figurantes: eles têm um rosto, um corpo, gestos muito seus, mas a encenação que os requisita pretende-os sem rosto, sem corpo, sem gestos seus.

Temos aliás frequentemente a impressão de que os figurantes se vingam da indiferenciação que Ihes é imposta com uma indiferença - discreta mas por vezes facilmente percetível - voltada contra a história, na qual eles esperam sentados. Nós vemo-los aborrecerem-se de morte, não esperar mais nada do cinema, quando todo o ator tem o direito de esperar que o cinema o faça aparecer. Será por isso que os figurantes representam tão mal, como que a contragosto? Ou então será porque o realizador simplesmente não sabe olhá-los, só tendo olhos para os seus "verdadeiros" atores? A coisa torna-se penosa quando é suposto que os figurantes incarnem um grupo de pessoas sujeitas ao mesmo destino trágico que os protagonistas, por exemplo nas representações hollywoodescas do tipo Holocausto ou Lista de Schindler. É insuportável, nestes casos, ver que os personagens de um filme não são iguais diante um mesmo destino que Ihes toca. Pelo contrário, Claude Lanzmann, como se sabe, dedicou muito do seu tempo a devolver o rosto, a palavra e os gestos àqueles a que os nazis chamavam Figuren nos campos. Mas não é uma tarefa impossível ou infinita, devolver a cada um a sua diferença, a sua singularidade, a sua irredutibilidade de ser falante?

Compreende-se, nestas condições, que os figurantes ponham ao cineasta uma questão crucial, indissoluvelmente estética, ética e política. Como filmar os figurantes? Como

\footnotetext{
${ }^{29}$ No original, Musée des Refroidis, expressão popular que, na gíria francesa, designa a morgue. [Nota da tradutora].
} 
fazê-los aparecer enquanto atores da história, como não se contentar de os fazer passar por indistintas sombras vivas? É aí que está toda a questão da relação estabelecida num filme entre a historieta e a história, a story local e a history onde ela acontece. Eisenstein dedicou-se, como é sabido, a inverter a relação estabelecida, no cinema hollywoodesco, entre a história-peripécia e a realidade histórica: em Hollywood, dizia ele, em traços gerais, põe-se no primeiro plano o inevitável trio constituído pelo marido, a mulher e o amante, depois escolhe-se - como se escolhe um papel de parede para casa - colocar atrás deles a "cor local" dos décors e da figuração, quer seja a Roma imperial, um safari africano ou Chicago dos anos $30^{30}$. Tratava-se de, pelo contrário, devolver aos figurantes, que são ao cinema aquilo que o povo é à história, os seus rostos, os seus gestos, as suas palavras e a sua capacidade de agir. De os filmar menos como uma massa e mais como uma comunidade, essa atriz principal - ativa e não passiva - da história real.

Em Potemkine, por exemplo, Eisenstein deteve-se bastante tempo sobre os rostos e os corpos dos seus figurantes para aí captar a forma como a morte de Vakoulintchouk suscita uma soberana transformação da dor pessoal (gestos religiosos de lamentação) em furor coletivo (gestos políticos de maldição e de apelo à vingança, tudo isto filmado em grande plano), e logo depois em decisão revolucionária. Para Outubro, a equipa de rodagem terá procurado incansavelmente os seus figurantes nas ruas, nos cafés, nos albergues. Entre as onze mil personagens solicitadas, muitas tinham sido protagonistas da verdadeira história, do tiroteio da Avenida Nevski ou da tomada do Palácio de Inverno, e decidiu-se, para a rodagem, distribuir-Ihes armas reais ${ }^{31}$. Eisenstein filma-os em planos largos e picados, mas posiciona-se também - no ritmo estonteante da sua montagem contrastada - rente ao chão para filmar, por exemplo, o rosto de um soldado caído numa poça de água.

Em A Greve, por fim, Eisenstein expõe tão cruamente quanto possível o corpo do povo, batendo-se contra a exploração que o aliena: corpos amarrados, corpos esmagados pelo trabalho e pelo sofrimento social (figuras 2 e 3). Nas últimas sequências do filme, ele confronta-se com o problema de representar o "horror sangrento" de um tiroteio em massa. O mínimo sinal de artifício teria a seus olhos arruinado a intensidade, e assim a necessidade, de uma tal cena. Para contornar a aporia de colocar em cena figurantes que sucumbem com mais ou menos convicção sob as balas de pólvora seca dos soldados, ele preferiu então pôr os seus figurantes na situação concreta de correr

\footnotetext{
30 S. M. Eisenstein, "Les principes du nouveau cinéma russe" (1930), La Revue du cinéma. Critique, recherches, documents, II, 1930, n 9, p. 20.

${ }^{31}$ Id., "Une armée de cent mille hommes devant les caméras" (1928), trad. A. Vitez, Octobre, Paris, Le Seuil/Avant-Scène, 1971, pp. 149-152.
} 
desenfreadamente numa ravina, de tal modo que a urgência física era, para cada um deles, bem real. O resultado é uma visão alucinante - mas praticamente documental de corpos verdadeiramente precipitados pelo seu próprio movimento de corrida (figura 4). Depois vemo-los caídos no chão sem que, mais uma vez, tenham que representar nada de particular (figura 5), enquanto Eisenstein inventa esse formidável contraponto que oferece a alegoria documental do boi degolado no matadouro, filmado em grande plano (figura 6): "Para evitar que os figurantes da Bolsa do Trabalho tivessem ar de representar [...] e sobretudo para eliminar o efeito de artifício que o ecrã não suporta e que é inevitável mesmo com a "agonia" mais brilhante, empreguei o seguinte procedimento [...] destinado a provocar o máximo efeito do horror sangrento: a alternância associativa do tiroteio com o matadouro. O primeiro, em planos de conjunto e planos médios, coloca em cena a queda de 1500 operários na ravina, a fuga da multidão, os tiros, etc... Ao mesmo tempo, todos os grandes planos servem para mostrar o horror do matadouro onde o gado é degolado e esfolado ${ }^{32}$."

Através destas escolhas formais, Eisenstein queria evidentemente devolver à massa a sua força: o seu papel de ator principal da história, mas também a especificidade dos seus gestos, da sua voz (o seu clamor, a sua palavra). E é por isso que os figurantes representavam, aos seus olhos, um problema estético fundamental. A questão põe-se ainda hoje: como filmar dignamente aqueles que não têm nome, aqueles que não têm outra voz senão o seu grito de sofrimento ou de revolta? Como aproximarmo-nos dos não atores, como olhá-los nos olhos, ouvir as suas palavras, respeitar os seus gestos? Há uma aposta deste género no cinema de Luis Buñuel e de Joris Ivens (a miséria exposta em Las Hurdes em 1932 e em Borinage em 1933), de Glauber Rocha e de Pier Paolo Pasolini até Aki Kaurismaki (onde vemos, em cada plano, a ternura, o respeito e mesmo a admiração deles pelo mais ínfimo figurante), de Jean Rouch e de Frederick Wiseman até Johan Van der Keuken (Le Masque, 1989), Michael Glawogger (Workingman's Death, 2005) ou ainda Wang Bing (com o seu admirável filme $A$ oeste dos trilhos), para citar apenas alguns exemplos ${ }^{33}$. Certos artistas contemporâneos não deixaram igualmente de interrogar o estatuto dos figurantes: Pawel Sala dedicou em 2002 um documentário aos figurantes do filme O pianista de Roman Polanski; Omer Fast, em 2003 realizou uma extraordinária instalação sobre os figurantes d'A Lista de Schindler de Steven Spielberg; e Krassimir Terziev dedicou toda uma série de obras aos

\footnotetext{
32 Id., "Le montage des attractions au cinema" (1924-1925), trad. A. Robel, QEuvres, I. Au-delà des étoiles, Paris, UGE-Cahiers du cinéma, 1974, pp. 132-133. Sobre o estreito parentesco desta montagem com o trabalho de Georges Bataille e de Eli Lotar sobre a figura humana no quadro da revista Documents, cf. G. Didi-Huberman, La Ressemblance informe, op. cit. p. 280-297.

${ }^{33}$ Cf., para outros exemplos, N. Brenez, Traitement du lumpenprolétariat par le cinema d'avant-garde, Biarritz-Paris, Séguier-Archimbaud, 2006.
} 
figurantes búlgaros "arrolados" em Hollywood para um sword and sandal sobre a guerra de Tróia ${ }^{34}$.

Ao decidir comemorar o centenário de $A$ Saída da Fábrica Lumière com um filme precisamente dedicado aos figurantes, Mohsen Makhmalbaf inventou, com Salaam cinema, um dispositivo complexo baseado num anúncio de casting para o qual se apresentaram ao realizador cinco mil pessoas. Filme sem atores "sobre aqueles que gostariam de fazer cinema". Filme sobre o desejo de cinema e sobre aqueles que, animados por um tal desejo, se veem confrontados no âmago das questões éticas que a vida nos põe: fazer figura ou desaparecer, calar-se ou tomar a palavra, submeter-se à ordem ou revoltar-se contra ela, ser julgado ou tornar-se juiz, contrabalançar a ficção com a mentira, a arte com a vida, a emoção composta com o afeto real, o riso com as lágrimas, o segredo íntimo com a história partilhada. No processo cruel mas socrático que põe em ação, Makhmalbaf acaba por fazer justiça aos figurantes aos quais o filme é dedicado: "Vocês representaram todos. Houve lugar para toda a gente. O cinema é um assunto de todos. Se o cinema fala da vida, então, há espaço suficiente ${ }^{35}$." Compreendamos aqui que um filme só teria justeza política na medida em que devolve o lugar e o rosto aos sem-nome, aos sem-parte na representação social habitual. Em suma, fazer da imagem um lugar do comum aí onde reinava o lugar-comum das imagens do povo.

\footnotetext{
${ }^{34}$ Cf. G. Lewis-Kraus, "Infinite Jetzt", Omer Fast. In Memory, dir. S. Schaschl, Bâle-Berlim, Kunsthaus Baselland-The Green Box, 2010, p. 56-63. J.-B. Joly (dir.), Krassimir Terziev: Extra Work. Taking the Figure of Extras in Cinema Production as Metaphor, Estugarda, Akademie Schloss Solitude, 2007.

${ }^{35}$ Cf. M. Haghighat e F. Sabouraud, Histoire du cinéma iranien, 1900-1999, Paris, Éditions BPI-Centre Georges Pompidou, 1999, p. 161-162. Cf. Igualmente A. Bergala, Abbas Kiarostami, Paris, Cahiers du cinéma, 2004, p. 67, que nota com pertinência como "Viagem em Itália [de Roberto Rossellini] e O vento levar-nos-à [de Abbas Kiarostami] terminam com a mesma moção: deixar o povo dos anónimos invadir o ecrã da ficção."
} 


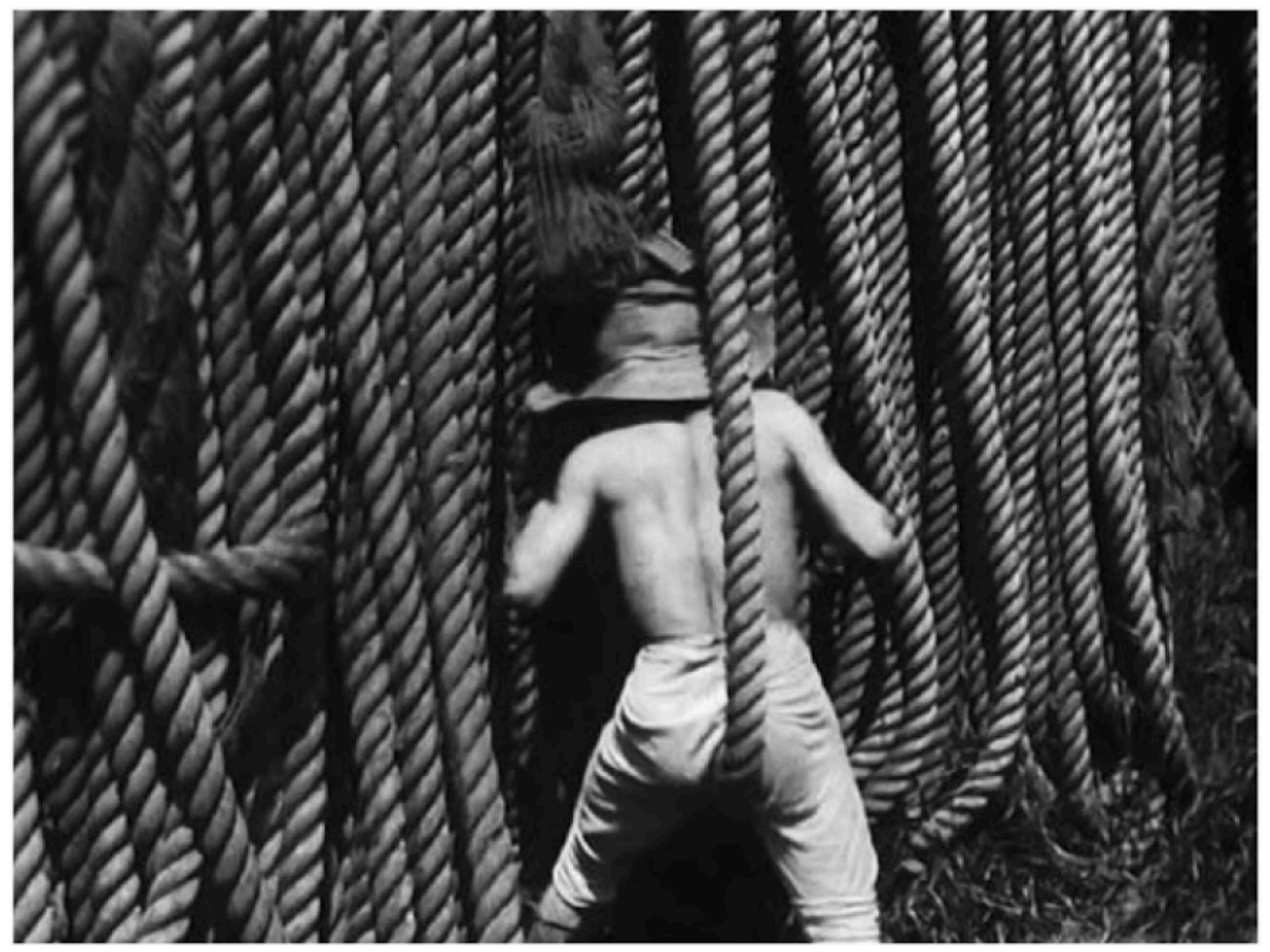

Figura 2: S. M. Eisenstein, A Greve, 1924. Fotograma do filme.

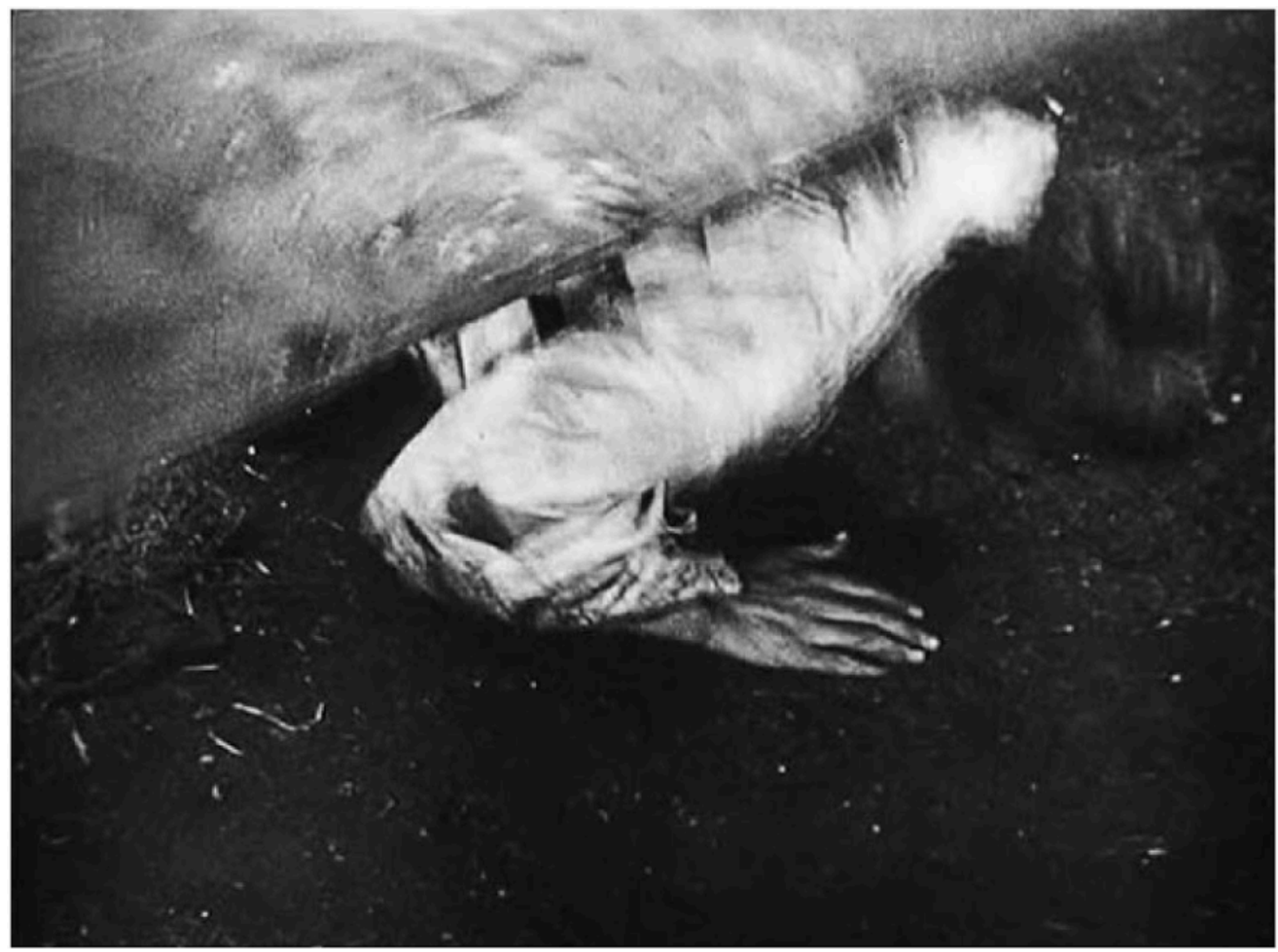

Figura 3: S. M. Eisenstein, A Greve, 1924. Fotograma do filme. 


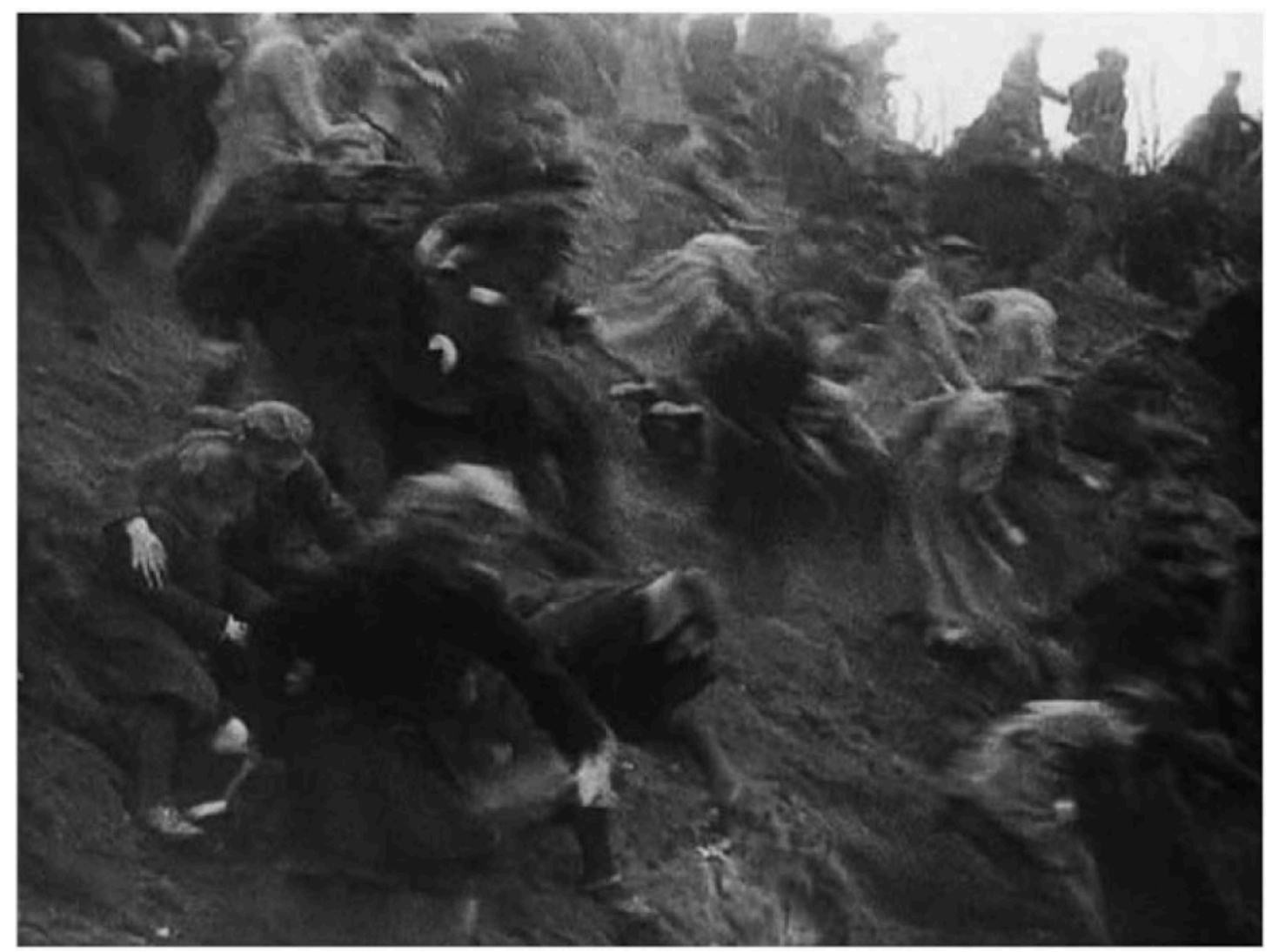

Figura 4. S. M. Eisenstein, A Greve, 1924. Fotograma do filme.

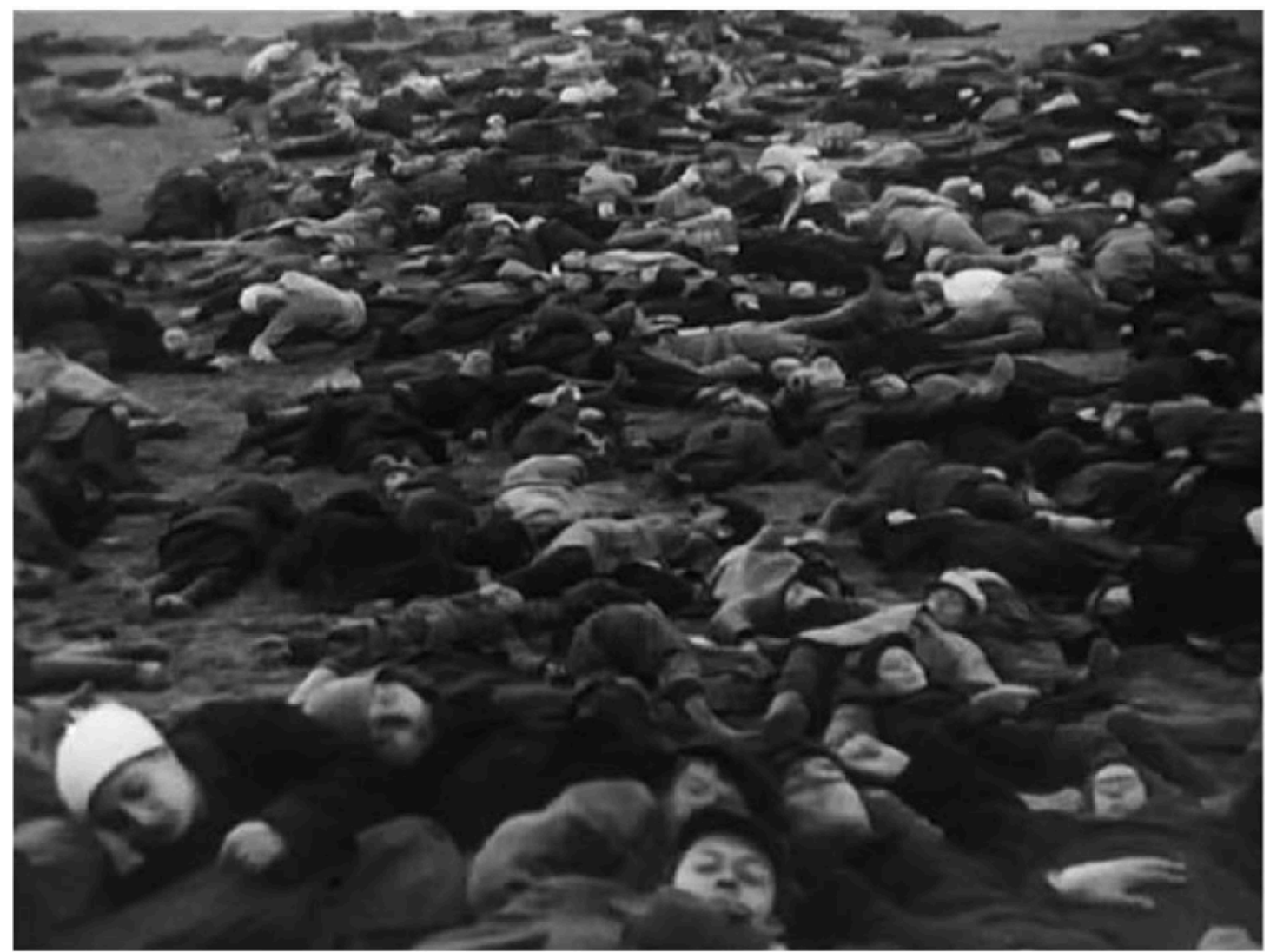

Figura 5: S. M. Eisenstein, A Greve, 1924. Fotograma do filme. 


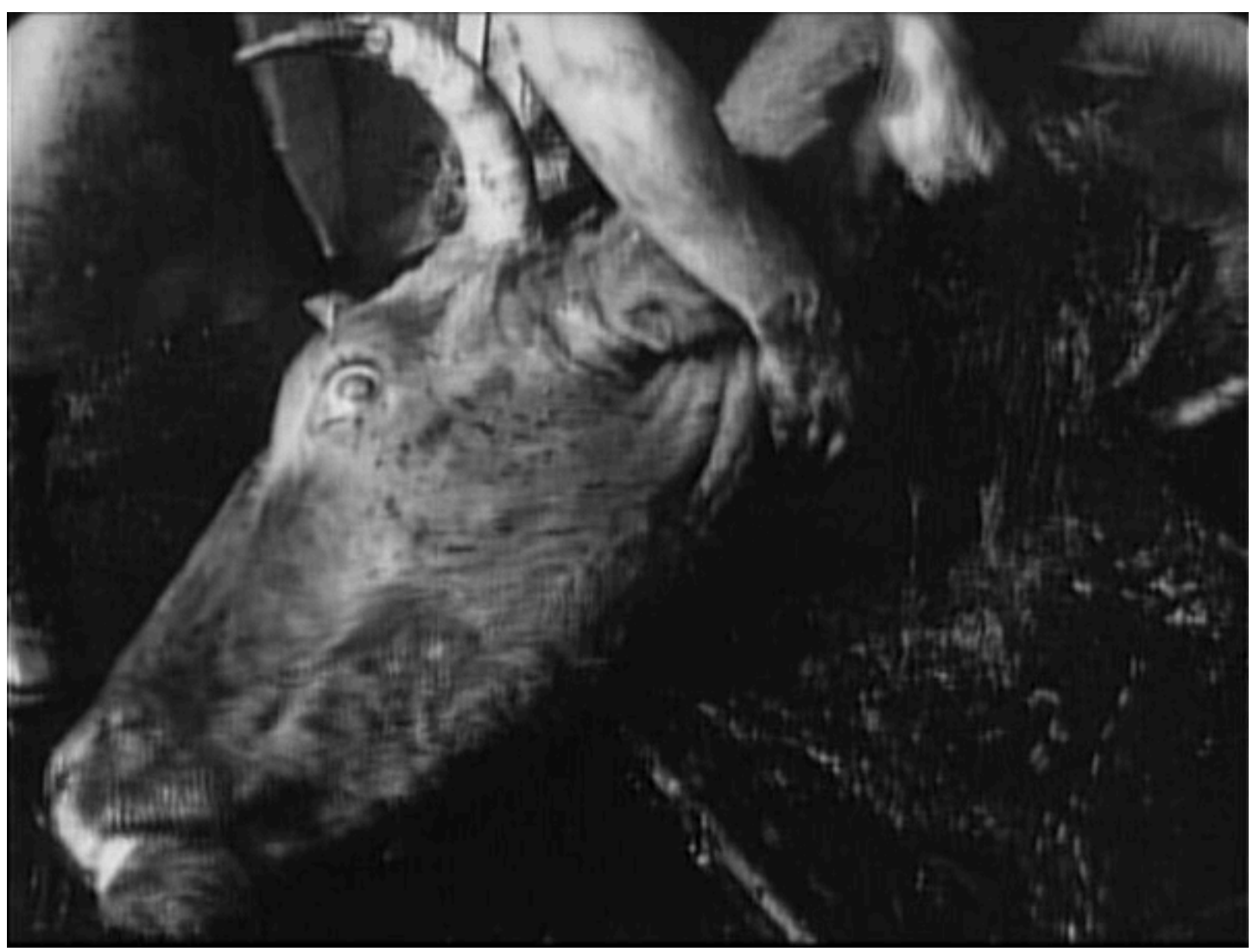

Figura 6: S. M. Eisenstein, A Greve, 1924. Fotograma do filme.

Maria da Luz Correia é doutorada em Ciências da Comunicação, pela Universidade do Minho e em Sociologia, pela Université Paris Descartes - Sorbonne. É atualmente Professora Auxiliar no Departamento de Línguas, Literaturas e Culturas na Universidade dos Açores. Investigadora do Centro de Estudos de Comunicação e Sociedade da Universidade do Minho, tem publicado na área da teoria da imagem e da história da fotografia.

\mariadaluzcorreia@gmail.com 